\title{
An Interview with Professor Jonathan King. Part I: on Social Responsibility and Activism in Academia
}

\author{
Manraj S. Gill ${ }^{1, *}$, Dylan M. McCormick ${ }^{1}$, and Jennifer A. Cascino ${ }^{1}$
}

For nearly four decades, Prof. King has served as a faculty member in the Department of Biology at MIT. His work on protein folding and, importantly, misfolding as they relate to human disease and virus assembly has garnered numerous awards and honors: He was a Woodrow Wilson National Fellow, Jane Coffin Childs Fund Fellow, AAAS Fellow, Guggenheim Fellow, and recipient of the National Institutes of Health (NIH) Merit Award. Additionally, Prof. King has taken critical roles at the intersection of science and public policy, including a tenure as President of the Biophysical Society in 1999. In 2003, he received the MIT Martin Luther King Leadership Award, which recognizes individuals who "embody the spirit of Dr. King's work" [1] in their contributions to the MIT community. Prof. King's recent efforts have focused on championing federal support for biomedical research as well as criticizing unrestrained defense spending. In part I of this interview, we examine the connections between science, activism, and policy through the lens of Prof. King's diverse experiences as an academic and activist.

Science Policy Review: How did your upbringing, education, and training influence your view of academic scientists as having a responsibility to the public and thereby acting as "public servants?"

Jonathan King: Before being a socially responsible scientist, I started by being a socially responsible citizen. I grew up and went to a public high school in Brooklyn. My parents were of the generation who lived through World War II. So early on, I learned from my parents that there were Nazis and fascists in the world, and to never assume that it couldn't happen here. You have to be constantly vigilant.

My own political consciousness was developed when I was in college during the time of the Civil Rights Movement and the Freedom Riders. And the danger of a nuclear war also ebbed and flowed in the United States; I went to my first demonstrations in New London against the Polaris submarines when I was an undergraduate at Yale.

But my awareness as a scientist came from being a graduate student (with Bob Edgar) at CalTech in 1962-1968. That was during the rise of the anti-war movement so we'd

\footnotetext{
${ }^{1}$ Department of Biology, Massachusetts Institute of Technology, Cambridge, MA *Email: manraj@mit.edu

The authors declare no conflict of interest. The opinions presented here represent the opinion of the speaker, not MIT Science Policy Review.

(C) 2021 The Author(s)
}

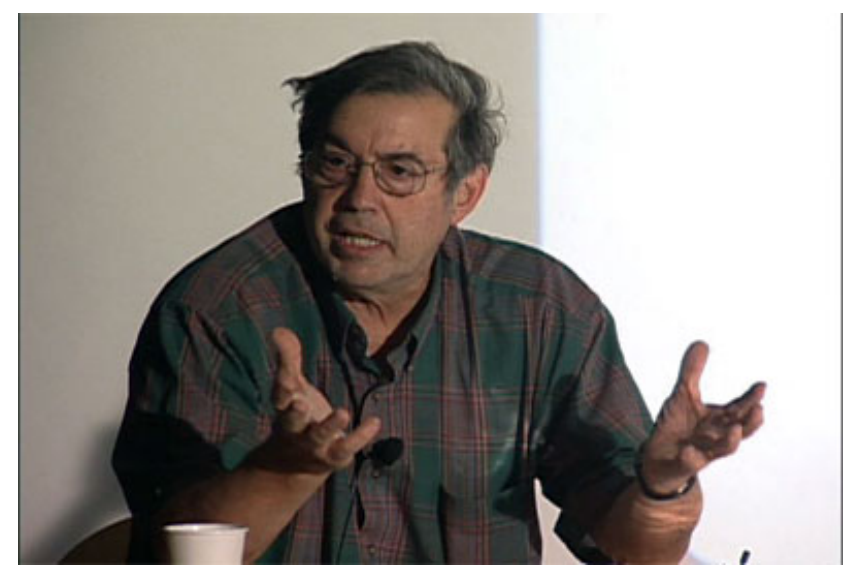

Figure 1: Professor Jonathan King speaking at an event hosted by the Technology and Culture Forum at MIT [2].

go up to Berkeley to join the marches. But CalTech had Linus Pauling. I was always interested in proteins and he was one of my scientific heroes. In 1963, when I was a graduate student, he got the Nobel Peace Prize - his second Nobel Prize for work on leading the atmospheric nuclear test ban. So I had that model to follow and that was also the first time I got the idea that scientists might have some extra responsibility.

I then went to England as a postdoctoral fellow, and the British scientific leadership had a very developed view that the need to resist the fascists had to be an international movement. And they articulated and wrote about scientists as an international community that had to resist fascism.

SPR: In your tenure as a scientist and activist, have you witnessed a shift in the way academic scientists are trained, particularly in the context of considering engagement with the public and public policy as a fundamental part of their job responsibilities?

JK: During my time as a graduate student, every campus in the United States had an anti-war organization. They were holding regular meetings, and you could just go to the meetings. You didn't have to show great initiative or high sensitivity. It was in the culture, it was in the environment. It's very different when it's in the culture and in the environment.

When I started as a faculty member, most of our graduate students came to MIT out of some general idealism that they could do something good in the world. It wasn't because they 
were going to make a lucrative career - there was no biotech industry. It was mostly, "How do we do something that is important?" That has absolutely changed.

The current faculty is a faculty who grew up as undergraduates and graduates around succeeding in their career: getting into the best schools, getting the best grades, getting the best graduate students, getting grants, etc. That is what they're focused on. In the middle of the pandemic, for almost all of my biology colleagues, the biggest thing on their mind was whether their NIH grant will be renewed. I don't put them down for that, I'm just reporting that it's very different to the past.

I'm still very active in electoral politics, so I chaired a group of 'Scientists For Markey' last year. You couldn't ask for a more respectable senator than Ed Markey. I wrote to all my colleagues in the Biology Department to join in or contribute. 1 in 5 responded. That's the level of disengagement. The careerism is very deep.

SPR: There are numerous established incentive structures for an academic scientist to perform the tasks associated with being a "career scientist," (namely research, teaching, mentoring, and departmental service) but seemingly fewer incentives for engaging with the broader public or participating in policy discourse. How do you envision the training process of an academic scientist can be updated going forward to actively incentivize such involvement?

JK: I don't know what the situation is now, but for the years that I was on the graduate committee, when the entering class arrived and we met with them and gave them their first checks, nobody said, "By the way, this money is not from MIT, this money is from American taxpayers. You are a public servant. Everyone's stipend checks are coming through the NIH budget voted on by Congress." Nobody ever said that. I would periodically propose that we inform the students about the origin of their funding, and I was always voted down. That's an issue l've fought over continuously and totally unsuccessfully.

I have also had battles over the past about the question, "Should all our graduate students have to take a seminar on social responsibility as scientists?" Nowadays the NIH mandates something on scientific integrity and ethics but it is usually very narrow. When we were fighting around these questions in our department, our committee's proposal included the development of a professional seminar in the graduate students' first semester where they would learn who sets the US budget: the role of the Congress, how it's done, the difference between an authorization and an appropriation, and the fact that Health and Human Services is starved because of the military industrial complex. Moreover, that the $\mathrm{NIH}$ budget is part of the Congressional discretionary budget and that one of the reasons the $\mathrm{NIH}$ budget is so small is because $55 \%$ of the discretionary budget goes to the Pentagon. The pie chart of the whole budget is an eye-opener, a 40 billion dollar NIH budget sounds like a lot to a graduate student, but when you see that it's $3 \%$ of the total operating budget and that a $25 \%$ increase for the $\mathrm{NIH}$ would only make it $4 \%$ of the total budget, then you would begin to question, "Why are we playing around with only $2-3 \%$ increases when 5 million people are coming down with Alzheimer's?"

You have to have that out there explicitly, and then you have to make it clear that the NIH is part of Health and Human Services. The focus is not on making sure that scientists can express themselves creatively but on national health priorities. The scientist would hopefully then be incentivized to not only put a portion of their time towards general social responsibilities, but to put some of their time towards making sure that the overarching goals of this public investment are met. The public investment is in health and welfare and not an investment in publish or perish.

"It was also a fight within the faculty

because if you want graduate

students to keep their nose in their

experiments, you don't want them

raising questions about women in

science, representation, health

$$
\text { policy, ..." }
$$

SPR: It seems like a lot of the onus in terms of changing the scientific culture falls on individuals who are most passionate about these issues. Do you think these responsibilities to the public can be more effectively upheld by dedicated full-time science communicators and community organizers employed by academic institutions?

JK: That's a good question, you get at the heart of it. So on the one hand, I believe it has to be part of everybody's responsibility. But you're going to need leadership. You can't ask everybody to put together a curriculum on science in society. There needs to be a leading group, both in the department, in the university, and nationally. That is absent right now.

Now there have been battles over this. We had a very robust faculty group at MIT about 20 years ago and we were pressuring MIT to establish courses on science, technology, and society within departments. We were influential enough to influence the administration. What they did is they established a program in Science, Technology, and Society. But it's located over at the Sloan School so a graduate student in biology is not going to be actively engaged. It was also a fight within the faculty because if you want graduate students to keep their nose in their experiments, you don't want them raising questions about women in science, representation, health policy, etc.

Now, there are a couple places in the country where they do reserve a tenure slot for someone who has that responsibility. It's better than nothing, but it requires one 
person to be kind of a hero. So that can be part of the solution, but it can also be part of the problem.

SPR: What lessons have you learned about managing your bandwidth, in regards to both time and effort, between academic tasks and constructive public service?

JK: Regarding the tension between the two, you're talking about what is a constant balancing act. Having to make a living is a very deep and important thing. Everybody has to make a living. You can't feel guilty about that. You have to recognize the importance of it. And then, since you don't get paid for the social work, and often you don't get any recognition, you have to squeeze that in wherever you can. Many of my academic colleagues didn't learn how to do that, and I have some close friends who got very passionate about some particular issue, and they put everything into it, but they didn't maintain their employment.

You have to walk on two legs here. You can't move both legs onto this path. You have to keep one leg on the other path. Now the secret is, you can't do it alone. This thing about being a responsible scientist, since there's no structures of support - you're not getting paid, you're not getting rewarded, you're not getting promoted - you have to have a collective.

There is the point about being able to sleep well at night. There are some things that don't advance your career, don't get you a publication, don't get you promoted. But you know that they need to be done so you can sleep well at night. It requires that there be enough people around you who know that you're doing this, and you get some social reward, even if it's a small-scale social reward. It's one of the reasons why I said you have to have a collective, otherwise you won't survive. I've dealt with it at MIT all my professional life and it's always been difficult. It required a few people who had some increased sensibility or sensitivity, and who weren't going to be silenced.

\section{"Now the secret is, you can't do it}

alone. This thing about being a

responsible scientist, since there's

no structures of support... you have

to have a collective."

SPR: It is commonly acknowledged that shaping and implementing ethical regulations on scientific products and technology requires constructive involvement from all affected stakeholders in the larger society. Namely, there is a need for both an informed public and also for "social organization that provides maximum opportunities for public debate, evaluation, and effective decision-making" [3]. What lessons have you learned about implementing social organization as an academic?

JK: I used to do a lot of traveling to universities, they'd invite me to give a talk about protein folding or virus structure, but then I would know some of the socially and politically active people, and l'd meet with them and tell them the same thing: this is an academic environment, everybody believes in educational learning. You've got an issue? Have a seminar on it. Give out an article to read, invite a speaker, follow the culture. The culture is not demonstrations, it's not shutting down the department, it's not sitting in at the dean's. The culture is education and communication. It doesn't have to be a fancy seminar, you don't need money. People love to speak, they don't have to be paid. But, the trouble is that for a person who's passionate, that can be a very mild, unsatisfying source of expression.

SPR: In light of the clear diminishing trust of the public in the enterprise of science and its technological applications, it is evident that the above responsibilities of the academic scientific community have not been sufficiently upheld in the recent decades. Do you think this has been a consequence of the academic community not imparting enough importance to these responsibilities or do you think that there are other forces at play?

JK: When we came on to the faculty, there were "Science for the People" groups. From Boston, Minnesota, Berkeley, to a dozen other campuses. And they often were cross-college. So "Science for the People" in Boston had faculty from MIT, Harvard, Tufts, etc. In this period, the '70s-' 80 s, these groups were very very consciously focused on the particular responsibility of scientists, the ability of scientists to make a contribution. Nowadays, there's fifty colleges and universities in the Boston area, but there's no mechanism for faculty from the different campuses to get together. And they never do, even when everybody is being hurt by the same problem that's hitting every one of the campuses. It's all siloed to death.

About two years ago, I went, along with the Bernie Sanders campaign, to a few campuses around the country trying to build anti-war campus faculty groups around the revived threat of nuclear war, and I would say we failed. We were not able to do that. All my life at MIT, I've worked on nuclear disarmament. MIT, despite being the leading contractor for conventional weapons research, was for decades the leading center of the opposition to nuclear weapons. But every year, we tried to recruit undergraduates into our group and generally failed.

A couple of years ago, in response to what was going on with Saudi Arabia and Raytheon, a very strong undergraduate group did form at MIT to take on the intimidating and powerful military-industrial complex, but on most campuses, such groups don't exist.

Moreover, we have an institution where people think it's okay for the MIT President to be in the arms of the worst military dictator, Mohammed bin Salman. And our faculty think that as long as we're getting some money from them then that's fine. We had a faculty move to try to force some kind of accountability on that, and it lost pretty strongly: roughly 200 to 50. We're not in a progressive institution, but at least it's an honest institution. It's not deeply corrupt.

One of the other things which made everything more difficult was the systematic reduction in public funding of 
universities that happened in the post-Reagan period. (see part II for a discussion on the influence of funding on education)

\section{"There are some things that don't}

advance your career, don't get you a

publication, don't get you promoted.

But you know that they need to be

done so you can sleep well at night."

SPR: Related to your activist efforts from within academia, how were these efforts received by the institutions you worked at? Did your efforts come up against interference? If so, how did you cope with those barriers? More generally, how should scientists be prepared, when they act in such social spaces, to handle pushback either from their colleagues or from their larger scientific community?

JK: To the first part of the question, that is often the thing that is socially controlling. If you get negative impact from your colleagues and you're someone who's not used to that, you just get incapacitated. And it is very hard to insulate people from that if they haven't experienced that before. And that's again a reason for why I say that you need to have a collective where you can discuss this. Because you have to be prepared for that and you have to expect it. Now it turns out that we normally don't talk about this to graduate students because graduate students are pampered. The faculty is terrified that you'll go somewhere else or you'll tell incoming students to go somewhere else. So, activism among graduate students is rarely going to lead to direct abuse.

It's different when you're an assistant professor. You get into the situation where the person is not trained to deal with the pushback and the first time they get up at a faculty meeting, the provost or the dean can be dismissive in response. This is very powerful at MIT, one of the only major universities in the United States where the President chairs the faculty meeting. Normally the chair of the faculty chairs the faculty meeting and the President is a guest at the meeting and can be questioned. So we have a very different situation internally.

So, if you're getting up to talk at such a meeting, you're directly confronting the powers that be. You just hope you have allies. For example, because all the women faculty got enraged over the treatment of the Epstein case, that weakened the administration who then had to be apologetic. Sometimes you luck out and you raise an issue that you're not the only group advocating for.

This also happened with the women faculty in the report by Nancy Hopkins where women in different departments were getting discriminated against in terms of office space and salary but they didn't know it! And Nancy brought together women faculty from multiple departments and they documented that it wasn't just Nancy who was mistreated, they all were being mistreated. So, the independently run faculty newsletter published Nancy's report which, once it was out there, all the MIT administrative heads had to respond to.

SPR: A continual point here seems to be that of collective action as a solution to some of these cultural issues within academia. We're also seeing the rise of a lot of graduate student unions across a number of academic institutions. We are curious about your thoughts on this shift and whether you see these as opportunities to change the culture in a very significant way.

JK: You know, if you can get a graduate student union, you open up opportunities to explore all kinds of issues: housing shortages, work requirements, abusive faculty mentors. A number of my graduate students, I won't name them, but a number of my most talented and successful graduate students came to work with me after initially signing up with somebody else who they found to be abusive. Now, MIT does have a graduate student association and that may offer opportunities and is a step in the right direction. For example, they have the housing subcommittee, and they have the opportunity to raise other issues including this one of general engagement, i.e. social and civic engagement.

I like graduate student unions, but I think at MIT it would be fought tooth and nail and because the faculty has no power at MIT, it would be very hard to get faculty support. At Rutgers, for example, the faculty are in a union and it is easy for the graduate students to organize because the President of their faculty union gives them protection.

\section{References}

[1] MIT Institute Community and Equity Office. MLK Leadership Award (2003). URL https://diversity.mit.edu/ mlk-programs/mlk-leadership-award.

[2] Massachusetts Peace Action. Foreign Policy for All Conference (2014). URL https://masspeaceaction.org/ welcome-to-foreign-policy-for-all-conference/.

[3] Luria, S. E. Slippery When Wet: Being an Essay on Science, Technology, and Responsibility. American Philosophical Society (1972). URL https://diglib.amphilsoc.org/ islandora/object/text:282405/\#page/1/mode/1up.

\section{Open Access}

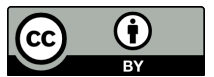

This MIT Science Policy Review article is licensed under a Creative Commons Attribution 4.0 International License, which permits use, sharing, adaptation, distribution and reproduction in any medium or format, as long as you give appropriate credit to the original author(s) and the source, provide a link to the Creative Commons license, and indicate if changes were made. The images or other third party material in this article are included in the article's Creative Commons license, unless indicated otherwise in a credit line to the material. If material is not included in the article's Creative Commons license and your intended use is not permitted by statutory regulation or exceeds the permitted use, you will need to obtain permission directly from the copyright holder. To view a copy of this license, visit http://creativecommons.org/licenses/ by $/ 4.0 /$. 